\title{
COMPETENCIES FOR FORM SIX GEOGRAPHY TEACHERS IN REACHING THE MALAYSIAN EDUCATION QUALITY STANDARDS
}

\author{
Hanifah Mahat*, Mohmadisa Hashim, Yazid Saleh, Nasir Nayan \& \\ Saiyidatina Balkhis Norkhaidi \\ Universiti Pendidikan Sultan Idris, Malaysia \\ *e-mail: hanifah.mahat@fsk.upsi.edu.my
}

\begin{abstract}
We conducted this study to evaluate the competencies of Form Six geography teachers in achieving the Malaysian Education Quality Standards. We applied a qualitative approach using the observation technique. The respondent observation consisted of three teachers who had more than 10 years of experience teaching Form Six geography and who were working in the areas of Batang Padang district, Perak and Hulu Selangor district, Malaysia. The variables we assessed were practical knowledge, subject-content knowledge, pedagogical content knowledge, pedagogical technology knowledge, teachers' teaching of professional behaviours and attitudes, and values modified from the Quality Level Rubric of the Malaysian Education Quality Standards. The observation findings showed that each teacher scored different points, ranging from three to four for the assessed variables. Teachers' pedagogical technology knowledge needs to be improved as two out of three teachers were still using Teaching Aid Materials such as mahjong paper and marker rather than using computer or other more recent technology due to the lack of infrastructure provided by their schools. In conclusion, Form Six geography teachers in this study have fulfilled the competence of the Malaysian Education Quality Standards by achieving the maximum score.
\end{abstract}

Keywords: competence, teacher, geography, Malaysian Education Quality Standards

\section{KOMPETENSI GURU GEOGRAFI TINGKATAN ENAM DALAM MENCAPAI STANDAR KUALITAS PENDIDIKAN MALAYSIA}

\begin{abstract}
Abstrak: Tujuan penelitian ini untuk mengevaluasi kompetensi guru geografi Tingkatan Enam dalam mencapai Standard Kualitas Pendidikan Malaysia. Penelitian menerapkan pendekatan kualitatif dengan menggunakan teknik observasi. Pengamatan responden terdiri atas tiga orang guru yang memiliki lebih dari 10 tahun pengalaman mengajar geografi Tingkatan Enam dan yang bekerja di daerah Batang Padang, Kabupaten Perak dan Hulu Selangor, Malaysia. Variabel dinilai adalah pengetahuan praktis, pengetahuan subjek-konten, pengetahuan konten pedagogis, pengetahuan teknologi pedagogis, pengajaran guru tentang perilaku dan sikap profesional, dan nilai-nilai yang dimodifikasi dari Rubrik Tingkat Kualitas Standard Kualitas Pendidikan Malaysia. Temuan pengamatan menunjukkan bahwa masing-masing guru mencetak poin yang berbeda, mulai dari tiga hingga empat untuk variabel yang dinilai. Pengetahuan teknologi pedagogik guru perlu ditingkatkan karena dua dari tiga guru masih menggunakan BahanBahan Pengajaran seperti kertas mahjong dan spidol daripada menggunakan komputer atau teknologi lainnya yang lebih baru karena kurangnya infrastruktur yang disediakan oleh sekolah mereka. Sebagai kesimpulan, guru geografi Tingkatan Enam telah memenuhi kompetensi Standard Kualitas Pendidikan Malaysia dengan mencapai skor maksimum.
\end{abstract}

Kata Kunci: kompetensi, guru, geografi, Tingkatan Enam, Standard Kualitas Pendidikan Malaysia

\section{INTRODUCTION}

Education in Malaysia has undergone dynamic changes to adapt to the current environment, and it will have future changes based on environmental demands. Several committees have been putting the national education through a series of evaluations. These committees came about in 1950 and stayed until the Murad Committee was established in 2004 to study the need to empower national schools. In addition, the Malaysian Education Quality Standards (SKPM), which was introduced in 
2010, shows that the evaluation system always faces evaluation and review processes to improve and enhance the country's education quality. The main purpose of conducting an evaluation and review is to determine a designated plan's effectiveness (Ministry of Education, 2009).

Evaluation in the teaching and learning of geography at both primary and secondary schools as well as in higher learning institutions has been one of the main issues in the field of geography education for a long time, in line with the advancement of science and technology. This situation has changed as geography became a completely elective subject in 1993 in Malaysia (Chuah \& Joseph, 2013). Due to this change, the subject of geography is becoming more isolated, which has had an impact on higher learning institutions. Seman\& Zuhir (2006) statetd that students' interest in taking geography, especially at the Form Six level, are very much lower than before in spite of the better textbooks, well-established curriculum and more qualified teachers. However, Hashim (2007) indicated the contrary: that a large number of students still choose geography as a minor subject at the university level.

Furthermore, students' interest in learning geography also varies among countries. Ozdemir (2012) provided evidence for this in a study he conducted in Turkey. He found that more than 80 per cent of students were interested in geography, which finding was similar to Ondigi's findings (2012), which demonstrated that over 90 per cent of school students liked and understood geography. These findings show that some factors affect whether geography is some students' main choice. Such factors include attitudes and interest in learning, students' career planning, students' abilities and skills, effectiveness of teachers' lessons, the subject's economic value, and the rewards factor vis-a-vis challenges in the field of study (Hisham, 2011).

Clearly, the educational development factor of geography as a school subject requires quality teaching as the current needs in the education sector are increasing day by day in line with technology. Teachers implementing an effective teaching and learning plan (PdP) should consider the use of delivery techniques, which can attract and stimulate students' interest both inside and outside the classroom. Effective teachers and teaching are essential to learning
(Hisham, 2011). According to Had (1998), one common theory in education is that a teacher's quality lies within the teacher's competence, and the teacher's quality then determines the students' learning quality and achievement. A statement issued by the Ministry of Education Malaysia (2009) also showed that only those with the quality, skills, credentials, qualifications, interest, commitment, and mentality of an educator are qualified to become teachers.

In addition, subsection 117 (a) of the Education Act 1996 provides the responsibility for Chief Inspectors of Schools (KNS) to ensure that satisfactory standards of teaching are established and maintained at educational institutions. Even though subsection 117 (a) focuses on the field of teaching, the field of management of educational institutions is also included within the scope of duties of KNS and Inspectors of Schools (NS) as provided in subsection 117 (b), (c), (d) and subsection 121. Realising the importance of implementing these responsibilities more effectively, in 2001, the Inspectorate of Schools (renamed the Inspectorate of Schools and Quality Assurance (JNJK) beginning in 2008) introduced a more systematic mechanism to setting a standard of continuously improving the quality of education in educational institutions. The mechanism is called Sistem Pemastian Peningkatan Standard Tinggi Kualiti Pendidikan (SPPSTKP), or the Standard Tinggi Kualiti Pendidikan (STKP).

However, the evaluation of teacher competence conducted by the Inspectorate of Schools and Quality Assurance (JNJK) has yet to reach a level to be proud of. Similarly, an evaluation of teachers' PdP found that the majority of teachers were teaching unidirectionally and teacher-centred. Geography education practitioners are taking various measures through teaching and learning methods to attract more students. However, because teachers have not well planned classroom activities nor in accordance with student abilities, the teachers have, as a result, failed to gain student attention during PdP (Ministry of Education, 2013). Therefore, competence is a standard that determines a teacher's performance level in carrying out duties and responsibilities and to achieve this goal, there is a dire need to identify existing teachers' competence, especially geography teachers', to 
meet today's call to develop the society and the nation for the changing times.

\section{Teacher's Competency in Achieving the Malaysian Education Quality Standards}

Education is the key element to the country's development in producing advancedminded citizens without marginalising the cultural, universal heritage, and sustainability of the natural resources aspects. Thus, in the field of education in Malaysia, teachers must move in line with the education direction drafted by the Ministry of Education Malaysia (MOE), which is to make Malaysia's education system a worldclass level. In evaluating teachers' readiness in educating and providing knowledge, a set of guidelines or standards has been introduced, called the Malaysian Teacher Standards (SGM), which outlines the professional competence that teachers must meet and the facilities that agencies and training institutions need to provide to assist teachers in reaching the specified competency level (Ministry of Education, 2009).

The professional competence that teachers must achieve includes the aspects of professional behaviours and values, knowledge and understanding, teaching, and learning skills. In general, competence refers to the knowledge, skills, and personal characteristics that are necessary to carry out tasks or responsibilities (Ibrahim, Razak, \& Kenayathulla, 2015) or the required abilities, knowledge, skills and attitudes one must have to handle tasks successfully (Carrarciao \& Englander, 2004; Sahin, 2004). From a general perspective, McClelland (1973) defined competence as a personal attitude or habit that leads to more effective work performance or, superiorly known as the ability that can improve individual socio-economic efforts at work. In addition, Hasibuan (2016) also defined competence as an individual's identifiable ability and efficiency as seen through the tasks that he or she carries out. According to Saedah \& Sani (2012), one might define competence in the field of education as the guidelines used for teachers to master various skill levels to meet both the students' and the community's needs. There are several elements contained within competency that involve the personality, actions, abilities, skills and knowledge of an individual in carrying out specified tasks or work. Apart from that, one can determine a presentation or delivery's effectiveness by way of the presenter's individual competence (Ridzwan, 2017) which is the core of human resource management (Che Ghani, Mohd Zaini \& Nur Faeeza, 2018). In the context of education, a teacher's excellent competence will have the impact of student success.

According to Nessipbayeva (2012), competence is interrelated with three measurable domains, namely knowledge, skills, and attitudes. There are five main components of competence, namely knowledge, skills, self-concept and values, characteristics, and motives (Tucker \& Cofsky, 1994). The knowledge component refers to the information and learning of an individual. The skills component refers to one's ability to perform certain tasks. The self-concept and values component refers more to one's attitude, values, and self-image. The characteristics component refers to a person's physical features and responses, which are consistent with the situation or information, while the motives component refers to the same emotions, desires, physiological needs, or impulses that act promptly (Figure 1).

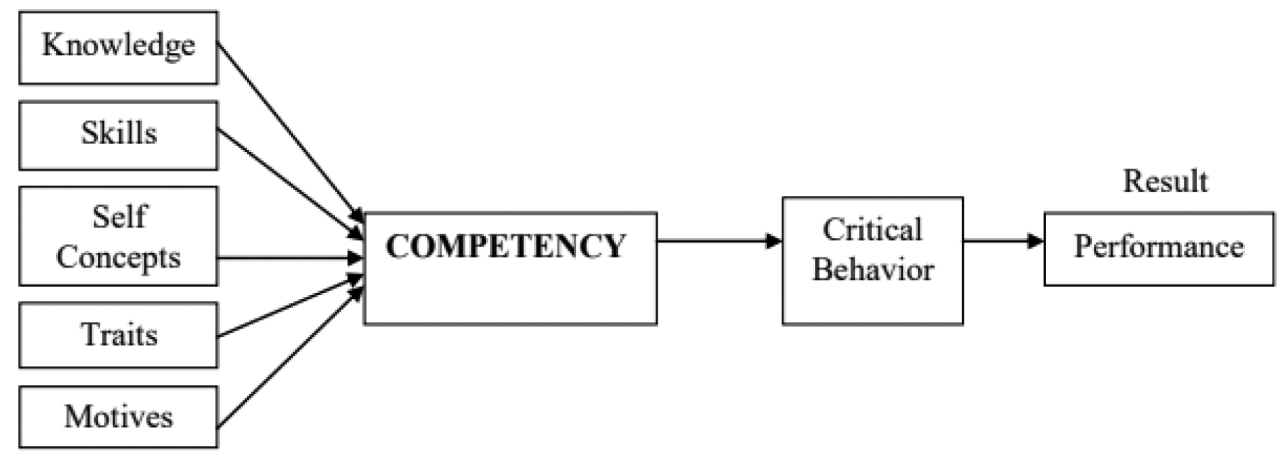

Figure 1. Competency Components

Source: Tucker \& Cofsky (1994) 
In addition, Weinert (1999) also elaborated on the idea by explaining that teacher competence can be categorised into two main elements, namely cognitive ability and affectivemotivational characteristics. Cognitive ability, also known as practical knowledge, is further divided into three elements, namely content knowledge, pedagogical content knowledge, and general pedagogical (Shulman, 1987). While affective-motivational characteristics can be categorised into two parts, namely beliefs, attitudes (content, instruction, schooling) and work motivation, personality and anxiety (Richardson, 1996) Overall, competence is an improvement in performance when one successfully implements everything necessary to carry out tasks and responsibilities for a job position.

The remuneration factor is also one of the key aspects in teacher competence that not only makes teachers excited to carry out their responsibilities effectively and excellently but also can result in student success. In addition, according to Veloo\&Raman (2013), when teachers have high levels of competency, their students evaluate them better and they have higher success rates and shows that an emphasis on student achievement, accountability and competence have an impact on the evaluation of teacher performance. Therefore, an emphasis on teacher competence through research is important to increase the production of a skilled or semiskilled workforce. Teachers are educators who need to have a high level of competence in terms of knowledge, skills, and attitudes.
In Malaysia, to ensure the teachers produce high quality work, three key aspects are emphasised, namely the practice of teaching professional values, knowledge, and understanding, as well as the practice of teaching and learning skills(Ministry of Education Malaysia, 2009), which are the Malaysian Teacher Standards (SGM). SGM aims to identify teachers' professional competence level in the practical aspect of teaching professional values, knowledge, and understanding as well as of teaching and learning skills, and of identifying teaching training agencies and institutions' preparation and implementation levels of the training requirements to ensure that teachers achieve high competence levels in all areas.

The SGM is a statement of professional competence that teachers need to meet(Standards) and a statement of the aspects that teaching training agencies and institutions need to prepare and implement (Requirements). The details of the SGM are based on five aspects, namely the National Mission, the National Education Philosophy (FPK), the Malaysian Teacher Philosophy (FPG), the Professional Teaching Conduct, and the Work Ethics of the Malaysia Ministry of Education. Figure 3 depicts the SGM. It has two main interconnected components, namely Standards (S) and Requirements (K). Standards are divided into three items, namely Standard 1: Teachers' Teaching Professional Behaviours and Values, Standard 2: Knowledge and Understanding, and Standard 3: PdP Skills. As for the Requirements component, the items comprise the following: Requirement

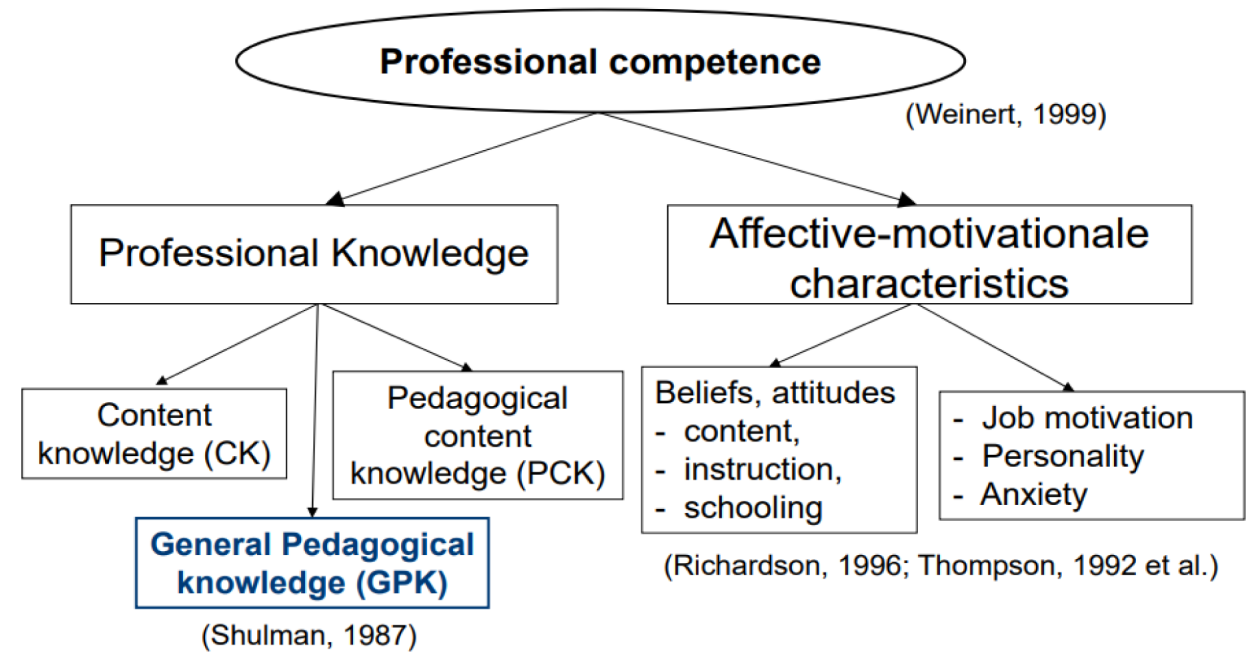

Figure 2. Teacher Competence

Source: Weinert (1999), Shulman (1987), \& Richardson (1996) 


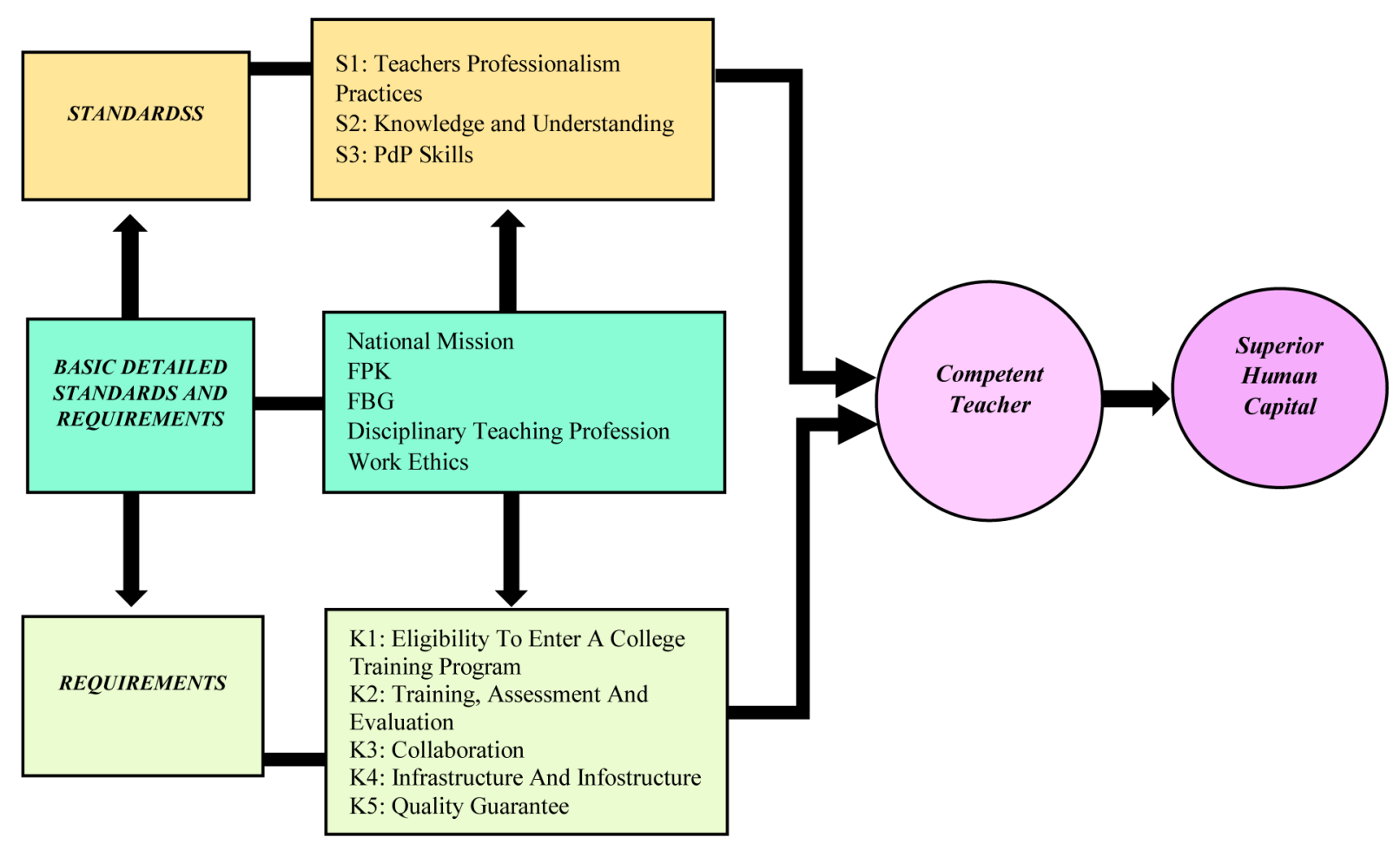

Figure 3. The Components of the Malaysian Teacher Standards

Table 1. Aspects of Malaysian Teacher Standards and Requirement

\begin{tabular}{|c|c|}
\hline Standard & Description \\
\hline Standard 1: Teacher Training & This standard details the competence of professionalism value \\
\hline Professionalism Value & $\begin{array}{l}\text { training based on the self-domain, profession and social, which } \\
\text { should be in a teacher. }\end{array}$ \\
\hline Standard 2: Knowledge and Understanding & $\begin{array}{l}\text { This standard details the competence of science and } \\
\text { understanding on subjects of specialization, science education, } \\
\text { curriculum and co-curriculum that a teacher should have. }\end{array}$ \\
\hline Standard 3: Learning and Learning Skills & $\begin{array}{l}\text { This standard details the competence of teaching and learning } \\
\text { skills that should be mastered a teacher. }\end{array}$ \\
\hline Requirement 1: Eligibility and Candidate & This requirement details the terms and criteria and procedures \\
\hline Recruitment Procedure Program & for recruitment of candidate training programs. \\
\hline $\begin{array}{l}\text { Requirement 2: Training, Assessment and } \\
\text { Assessment }\end{array}$ & $\begin{array}{l}\text { This requirement details training programs, monitoring systems, } \\
\text { and assessments and assessments. }\end{array}$ \\
\hline Requirement 3: Collaboration & $\begin{array}{l}\text { This requirement details the collaboration between the agency } \\
\text { and institutional training institutes with the parties schools, local } \\
\text { and foreign higher educational institutions, non-governmental } \\
\text { organizations and other institutions which can further strengthen } \\
\text { teacher training. }\end{array}$ \\
\hline $\begin{array}{l}\text { Requirement } 4 \text { : Infrastructure and } \\
\text { Infostructure }\end{array}$ & $\begin{array}{l}\text { This requirement details the teaching and learning infrastructure, } \\
\text { information and communication for optimizing the efficiency and } \\
\text { effectiveness of training programs. }\end{array}$ \\
\hline Requirement 5: Quality Assurance & $\begin{array}{l}\text { This requirement details all aspects of planning and implementation } \\
\text { of policies, strategies, procedures and activities to create } \\
\text { confidence that the quality of training is always maintained and } \\
\text { enhanced continuous. }\end{array}$ \\
\hline
\end{tabular}

1: Entry-level qualifications to a teaching training programme; Requirement 2: Training, Assessment, and Evaluation; Requirement 3:
Collaboration; Requirement 4: Infrastructure and Infostructure; and Requirement 5: Quality Assurance. 
The details of the standard and the requirements outlined are very important to ensure that the training program implemented will produce teachers who are competent, creative, innovative, and skilled. The standard and requirement covers the three aspects as in Table 1.

Figure 4 shows the Malaysian Teacher Standards. Letter G represents the teachers, whom Malaysia requires to have high competence in the practical aspect of teaching professional values (Standard 1), knowledge and understanding (Standard 2), and teaching and learning skills (Standard 3). The three overlapping circles represent all three standards, which means that the three aspects of competence that teachers must master are interrelated and integrated. The large circle that encapsulates the requirements represents the basic set of Standards and Requirements, namely the National Mission, National Education Philosophy, Teacher Education Philosophy, Teaching Professional Conduct and Work Ethics of the Malaysia Ministry of Education. The globe in the middle of the Standards circle refers to the world-class quality teachers who have the responsibility of developing first-class-minded human capital, i.e. students who master the knowledge and high skills, uphold the nation's cultural values, have the spirit of complete patriotism, and have high competence and credibility.

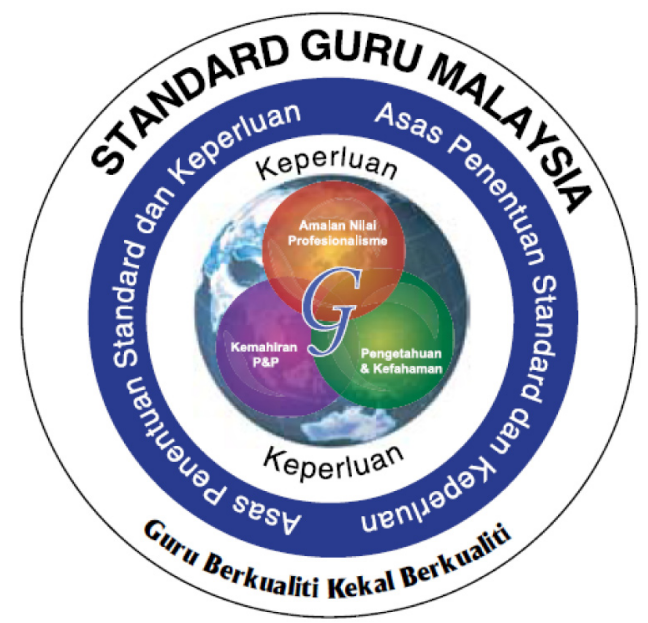

Figure 4. The Malaysian Teacher Standards Model

In the Malaysian context, a debate by Saedah \& Sani (2012) regarding the implications of Malaysia's lack of competency standards in the education field will relate to service problems, occupational stress, role conflict, role ambiguity, the absence of a social support system from the principal and colleagues (which has caused many teachers to resign or retire early), and burnout among teachers. This situation has affected the quality of our national education. In 2013, after KPM set a target for general teacher competence, the problems researchers discussed are still happening among teachers. Clearly, the education system needs a detailed study to be done regarding teacher competence, not just in general, but according to their respective subjects or areas of teaching. Such a detailed study must include geography teachers' competence in the two basic areas of geography, namely physical geography and human geography, which pre-university level teachers should master, in line with the development of geography which is a non-static knowledge. The knowledge in geography teaching involves teaching knowledge, curriculum knowledge, knowledge organisation, and geography teaching approaches that are necessary for geography teachers (Karademir, 2016). Thus, the evaluation of teacher competence is important to ensure that teachers have guidance that can lead them in determining their competence level.

\section{METHOD}

We used a qualitative approach in this study to meet the requirements of a detailed data collection on behaviour and interaction (Smith, 2004) and we did not manipulate the environment nor the experience (McMillan \& Schumacher, 1989). In this study, we modified the observation method involving components of SKPM (Ministry of Education Malaysia, 2009) and we used Standard 4: Learning and Facilitation (School) to obtain the study data. In the observation session, we sought out three teachers for each school who had more than 10 years of experience teaching Form Six geography and who were working in the Batang Padang district, and in the Perak and Hulu Selangor district, Malaysia.

Observation is a method of observing, taking notes and recording the events and behaviours in the field studied. The validity of the observation form involves three qualitative experts to confirm this observation form. Even though the researcher is observing the behaviour of the subjects, the researcher does not influence 
the study participants to behave in a certain way. With such internalisation, the researcher will have an actual perception of the information collected (Konting, 2000). In this study, the researchers observed the respondents' teaching and learning sessions in the classroom to obtain information on the geography teachers' competence in the Malaysian Teacher Standards components. Researchers carried out the evaluation during the entire period of the PdP based on the checklist provided earlier. The observation in this study was based on items that were built earlier. The constructed observation items comprised the items acquired and modified from Standard 4: Learning and Facilitation (School). The items included five aspects, namely practical knowledge, subject-content knowledge, pedagogical content knowledge, pedagogical technology knowledge and teachers' teaching of professional behaviours and values (Appendix).

\section{FINDINGS AND DISCUSSION}

We will discuss here the findings and discussion of the study in the five aspects: practical knowledge, subject-content knowledge, pedagogical content knowledge, pedagogical technology knowledge and teachers' teaching of professional behaviours and values. All aspects were the items obtained and modified from Standard 4: Learning and Facilitation (school), which included those just mentioned plus student feedback.

\section{Findings \\ Teaching Practical Knowledge}

In the aspect of teaching practical knowledge, a teacher should guide the students by providing demonstration of mastering the lessons' content, concepts, and facts related to the lesson, providing guidance and demonstration on mastering the skills in learning activities, guiding students on decision making and problem solving in the learning activities, guiding students in utilising or making use of the educational resources with regard to the lesson and connecting the lesson content with the topic, unit, theme, value, skill, or other subjects in the learning activities. We based the evaluation scoring on the Quality Level (TK) Rubric observation instrument in the Appendix. Two observers each provided observation scoring for Teacher 1, Teacher 2, and Teacher 3. The observers gave different evaluation marks for each of the three teachers in the area of teaching practical knowledge. However, the marks were between three and four for implementing the action according to the needs/levels of the students' ability, correctly and accurately, prudently and earnestly (Table 2).

\section{Subject-content knowledge}

As for the aspect of subject-content knowledge, teachers control the learning process by managing the planned lesson content/learning scope, managing the PdPc time in accordance with the learning activities, and providing

Table 2. Teachers' Scores for Teachers' Teaching Practical Knowledge

\begin{tabular}{|c|c|c|c|}
\hline \multirow{2}{*}{ Teacher } & \multicolumn{2}{|c|}{ Score } & \multirow{2}{*}{ Note } \\
\hline & Observer 1 & Observer 2 & \\
\hline Teacher 1 & 4 & 3 & $\begin{array}{l}\text { Actions are implemented: } \\
\text { i. based on the needs/various levels of student ability. } \\
\text { ii. correctly and accurately. } \\
\text { iii. prudently. } \\
\text { iv. earnestly. }\end{array}$ \\
\hline Teacher 2 & 4 & 4 & $\begin{array}{l}\text { Actions are implemented: } \\
\text { i. based on the needs/various levels of student ability. } \\
\text { ii. correctly and accurately. } \\
\text { iii. prudently. } \\
\text { iv. earnestly. }\end{array}$ \\
\hline Teacher 3 & 3 & 3 & $\begin{array}{l}\text { Implementedfor any three ( } 3 \text { ) actions: } \\
\text { i. based on the needs/various levels of student ability. } \\
\text { ii. correctly and accurately. } \\
\text { iii. prudently. } \\
\text { iv. earnestly. }\end{array}$ \\
\hline
\end{tabular}


Table 3. Teachers' Scores for Teachers' Subject-Content Knowledge

\begin{tabular}{|c|c|c|c|}
\hline \multirow{2}{*}{ Teacher } & \multicolumn{2}{|c|}{ Score } & \multirow{2}{*}{ Note } \\
\hline & Observer 1 & Observer 2 & \\
\hline Teacher 1 & 4 & 3 & $\begin{array}{l}\text { Actions are implemented: } \\
\text { i. by meeting the lesson objectives. } \\
\text { ii. according to the different levels of student ability/ } \\
\text { differentiated learning. } \\
\text { iii. continuously in PdPc. }\end{array}$ \\
\hline Teacher 2 & 4 & 4 & $\begin{array}{l}\text { Actions are implemented: } \\
\text { i. by meeting the lesson objectives. } \\
\text { ii. according to the different levels of student ability/ } \\
\text { differentiated learning. } \\
\text { iii. continuously in PdPc. }\end{array}$ \\
\hline Teacher 3 & 3 & 3 & Implemented for any (i) and (ii) actions or (i) and (iii) actions. \\
\hline
\end{tabular}

Table 4. Teachers' Scores for Teachers' Pedagogical Content Knowledge

\begin{tabular}{|c|c|c|c|}
\hline \multirow{2}{*}{ Teacher } & \multicolumn{2}{|c|}{ Score } & \multirow{2}{*}{ Note } \\
\hline & Observer 1 & Observer 2 & \\
\hline Teacher 1 & 4 & 3 & $\begin{array}{l}\text { Actions are implemented: } \\
\text { i. by meeting the lesson objectives. } \\
\text { ii. according to the different levels of student ability/ } \\
\text { differentiated learning. } \\
\text { iii. continuously in PdPc. }\end{array}$ \\
\hline Teacher 2 & 4 & 4 & $\begin{array}{l}\text { Actions are implemented: } \\
\text { i. by meeting the lesson objectives. } \\
\text { ii. according to the different levels of student ability/ } \\
\text { differentiated learning. } \\
\text { iii. continuously in PdPc. }\end{array}$ \\
\hline Teacher 3 & 3 & 3 & Implemented for any (i) and (ii) actions or (i) and (iii) actions. \\
\hline
\end{tabular}

opportunities for students' active participation. Table 3 shows that all three teachers have different evaluation scores for subject-content knowledge, with the score values of three and four for implementing actions according to the learning objectives, according to various levels of student ability/differentiated learning and continuity in the PdPc.

\section{Pedagogical Content Knowledge}

In the aspect of pedagogical content knowledge, teachers control the learning environment by monitoring students' communication in $\mathrm{PdPc}$, monitoring students' behaviour in $\mathrm{PdPc}$, organising student rankings and creating a fun learning environment. Table 4 shows the scores of all three teachers with different evaluation marks for pedagogical content knowledge, with the scores of three and four for implementing actions prudently, and comprehensively and continuously including all students in PdPc, based on the learning activities.

\section{Pedagogical Technology Knowledge}

In terms of pedagogical technology knowledge, teachers plan a PdPc implementation by preparing an RPH containing measurable objectives and appropriate learning activities, determining the assessment methods in PdPc and providing Teaching Aid Tools (ABM)/Teaching Aid Materials (BBM)/Learning Aid Materials (BBB)/Information and Communication Technology (TMK). Table 5 shows the scores of all three teachers with different evaluation marks for pedagogical technology knowledge, with the scores three and four for implementing an action according to the various levels of student ability, within the time allocated and in compliance with the curriculum/instructional standards in effect. 
Table 5. Teachers' Scores for Pedagogical Technology Knowledge

\begin{tabular}{|c|c|c|c|}
\hline \multirow{2}{*}{ Teacher } & \multicolumn{2}{|c|}{ Score } & \multirow{2}{*}{ Note } \\
\hline & Observer 1 & Observer 2 & \\
\hline Teacher 1 & 4 & 3 & $\begin{array}{l}\text { Actions are implemented: } \\
\text { i. according to the various levels of student ability. } \\
\text { ii. according to the specified time limit. } \\
\text { iii. by adhering to the curriculum/instructional standards in } \\
\text { effect. }\end{array}$ \\
\hline Teacher 2 & 4 & 3 & Implemented for any (i) and (ii) actions or (i) and (iii) actions. \\
\hline Teacher 3 & 3 & 4 & $\begin{array}{l}\text { Actions are implemented: } \\
\text { i. according to the various levels of student ability. } \\
\text { ii. according to the specified time limit. } \\
\text { iii. by adhering to the curriculum/instructional standards in } \\
\text { effect. }\end{array}$ \\
\hline
\end{tabular}

Table 6. Teachers' Scores for Teachers' Teaching Professional Behaviours and Values

\begin{tabular}{|c|c|c|c|}
\hline \multirow{2}{*}{ Teacher } & \multicolumn{2}{|c|}{ Score } & \multirow{2}{*}{ Note } \\
\hline & Observer 1 & Observer 2 & \\
\hline Teacher 1 & 3 & 3 & Implemented for any (i) and (ii) actions or (i) and (iii) actions. \\
\hline Teacher 2 & 4 & 4 & $\begin{array}{l}\text { Actions are implemented: } \\
\text { i. with the involvement of } 90 \% \text { to } 100 \% \text { of students for action } \\
\text { (i), (ii) and (iii) and the involvement of over } 50 \% \text { of students } \\
\text { for action (iv), (v), (vi) and (vii). } \\
\text { ii. in line with the objectives of the lesson. } \\
\text { iii. confidently. } \\
\text { iv. prudently/respectfully towards each other/earnestly. }\end{array}$ \\
\hline Teacher 3 & 4 & 4 & $\begin{array}{l}\text { Actions are implemented: } \\
\text { i. with the involvement of } 90 \% \text { to } 100 \% \text { of students for action } \\
\text { (i), (ii) and (iii) and the involvement of over } 50 \% \text { of students } \\
\text { for action (iv), (v), (vi) and (vii). } \\
\text { ii. in line with the objectives of the lesson. } \\
\text { iii. confidently. } \\
\text { iv. prudently/respectfully towards each other/earnestly. }\end{array}$ \\
\hline
\end{tabular}

\section{Teachers' Teaching of Professional Behaviour and Values}

As for the aspect of teachers' teaching professional behaviours and values, teachers encourage students' emotions in carrying out learning activities by giving praise and encouragement towards positive behaviours, showing appreciation for good works/ideas, giving confidence in asking questions/responding and being concerned about students' needs. Table 6 shows the scores of all three teachers with different evaluation marks of teachers' teaching professional behaviour and values with three scores for Teacher 1 and four each for Teachers 2 and 3 . The observers evaluated the teachers during the time when the teachers were prudently carrying out an action, comprehensively and continuously/consistently including all students.

\section{Student Feedback}

As for the aspect of student feedback, students are involved in the learning process by responding to the lesson content, communicating when carrying out the learning activities, carrying out learning activities collaboratively, responding that leads to critical and creative thinking related to the lesson content, asking questions related to the lesson content, associating lesson content with student life/local/global issues and making decisions/solving problems related to the learning activities. Table 7 shows the different scores of student feedback on teachers' teaching. In general, the students who were 18 and 19 years of age gave good feedback on the lesson of these teachers due to the maturity level. 
Table 7. Teachers' Scores for Student Feedback

\begin{tabular}{|c|c|c|c|}
\hline \multirow{2}{*}{ Teacher } & \multicolumn{2}{|c|}{ Score } & \multirow{2}{*}{ Note } \\
\hline & Observer 1 & Observer 2 & \\
\hline Teacher 1 & 3 & 4 & $\begin{array}{l}\text { Actions are implemented: } \\
\text { i. with the involvement of } 90 \% \text { to } 100 \% \text { of students for action } \\
\text { (i), (ii) and (iii) and the involvement of over } 50 \% \text { of students } \\
\text { for action (iv), (v), (vi) and (vii). } \\
\text { ii. in line with the objectives of the lesson. } \\
\text { iii. confidently. } \\
\text { iv. prudently/respectfully towards each other/earnestly.). }\end{array}$ \\
\hline Teacher 2 & 4 & 4 & $\begin{array}{l}\text { Actions are implemented: } \\
\text { i. with the involvement of } 90 \% \text { to } 100 \% \text { of students for action } \\
\text { (i), (ii) and (iii) and the involvement of over } 50 \% \text { of students } \\
\text { for action (iv), (v), (vi) and (vii). } \\
\text { ii. in line with the objectives of the lesson. } \\
\text { iii. confidently. } \\
\text { iv. prudently/respectfully towards each other/earnestly.. }\end{array}$ \\
\hline Teacher 3 & 4 & 3 & $\begin{array}{l}\text { Actions are implemented: } \\
\text { i. with the involvement of } 70 \% \text { to } 89 \% \text { of the students for } \\
\text { action (i), (ii) and (iii) and the involvement of more than } 25 \% \\
\text { to } 49 \% \text { of the students for action (iv), (v), (vi) and (vii). } \\
\text { ii. by fulfilling at least two (2) of item (ii), (iii) or (iv). }\end{array}$ \\
\hline
\end{tabular}

Furthermore, the observation results show that teachers using BBM, such as presentation with mahjong paper managed to gain students' attention and simultaneously make them interested in the teaching content.

\section{Discussions}

\section{Teaching Practical Knowledge}

The observers gave different evaluation marks for each of the three teachers in the area of teaching practical knowledge. However, the marks were between three and four for implementing the action according to the needs/ levels of the students' ability, correctly and accurately, prudently and earnestly. This is in line with the opinion of Nur Soleha (2012) who associated teacher professional standards with competence in some aspects, such as planning lessons that can ensure high levels of student achievement and maintaining a learning environment that can contribute to effective delivery of information. Therefore, we conclude that the teachers involved in this observation session successfully created an effective teaching strategy when in the classroom or workshop (Yahaya, Hashim \& Azizuddin, 2006).

\section{Subject-content knowledge}

Finding shows that all three teachers have different evaluation scores for subject-content knowledge, with the score values of three and four for implementing actions according to the learning objectives, according to various levels of student ability/differentiated learning and continuity in the PdPc. This is because the mastery of subject-content knowledge is an important element that every teacher needs to have. This mastery includes an understanding of the concepts, theories, ideas, organisational framework as well as the appropriate approaches and practices (Shulman, 1986). When a teacher completes and effectively delivers subjectcontent knowledge, they are ensuring student learning in the classroom (Kasim \& Tamuri, 2010).

\section{Pedagogical Content Knowledge}

Findings shows the scores of all three teachers with different evaluation marks for pedagogical content knowledge, with the scores of three and four for implementing actions prudently, and comprehensively and continuously including all students in PdPc, based on the learning activities. This is because pedagogical knowledge requires cognitive understanding, social, learning-theory development, and methods to apply it among students in the classroom. Pedagogical content knowledge includes teaching, learning, curriculum, evaluation, and reports (Koehler,Mishra,\& Cain, 
2013). Furthermore, this finding is also in line with Mohammad Rusdi's (2017) opinion when he described pedagogical content knowledge as a particular knowledge for teachers to as teachers' understanding on the subject content is different from that of field experts. The teachers in this study managed to apply the teaching methods, which include inductive and deductive methods, and teaching approaches using various methods such as conceptual comparison and contextual teaching with subject pedagogical knowledge (Kasim \& Tamuri, 2010).

\section{Pedagogical Technology Knowledge}

The results of this study indicate that teachers involved in this study understand the relationship between teaching and learning, including the ways in which they are changing in line with the development of technology (Koehler, et al., 2013). The observation in this study showed that two out of three teachers used computers and LCD projectors in PdPc sessions. However, a whiteboard was placed at the front of the classroom and was controlled by the teacher to add information from the slides displayed through the computer. This means that teachers should be creative and thinking out of the box in order to use the technology and then apply the technology in the teaching and learning sessions (Koehler, et al., 2013).

\section{Teachers' Teaching of Professional Behaviour and Values}

The results indicate that two teachers involved were able to control emotions, timely and to carry out actions prudently in line with the category of teachers' teaching professional behaviours and values. In Abdul Shukor's (2005) study, Shukor listed 12 characteristics of a students' favourite teacher, which included diversifying the teaching and learning methods to attract students, and teachers who are always prepared before entering the classroom or workshop. Teaching can be done more effectively when teachers are better prepared, in fact, time will not be wasted because teachers are ready to teach the subject content and deliver it to the students (Che Ghani, Mohd Zaini \& Nur Faeeza, 2018). In addition, the findings also showed that teachers retain high standards of professionalism when communicating with students while displaying behaviours that are appropriate in their professions such as maintaining their dignity and credibility.

\section{CONCLUSION}

Overall, the observation findings demonstrated that each teacher scored differently. The scores were between three and four for practical knowledge, subject-content knowledge, pedagogical content knowledge, pedagogical technology knowledge, teachers' attitude and teaching of professional behaviours and values. Teachers' pedagogical technology knowledge needs improvement as two out of three teachers were still using BBM such as mahjong paper and marker rather than using more modern technology, such as computers, due to the lack of infrastructure provided by the schools. However, student feedback showed that the students were active in PdPc sessions due to the maturity age factor of 18 years old and 19 years old. Therefore teacher will need to work through the standards and begin to reflect and critique their own practices from different perspectives. They must begin to make appropriate changes and decision for the training of their students.

In conclusion, the competence of Form Six geography teachers has successfully achieved the Malaysian Education Quality Standards (SKPM) but there are components that need improvement, such as pedagogical technology knowledge. In addition, we would recommend a more detailed study involving the participation of prospective teachers, less experienced teachers and experienced teachers for future studies to address the problems in terms of teacher competence based on different years of experience and to develop action plans to be presented to certain parties.

\section{ACKNOWLEDGEMENTS}

This study was conducted with the help of University Research Grant (GPU 20180040-107-01). We give the highest gratitude to Universiti Pendidikan Sultan Idris for providing the research funding and to all Form Six geography teachers involved in the study.

\section{REFERENCES}

Carrarciao, C. \& Englander, R. (2004). Understanding competency-base education. London: Routlegde Inc. 
Che Ghani, C. K., Mohd Zaini, O. \& Nur Faeeza, A. G. (2018). Competence of instructor in practicing teaching of furniture manufacturing in Malaysia. Sains Humanika, 10(3), 25-32.

Chuah, W. R. \& Joseph. (2013). Isu pengajaranpembelajaran geografidan amalan refleksi kendiri dalam kalangan guru pelatih Institut Pendidikan Guru Malaysia. Paper presented in Seminar Pendidikan Sejarah dan Geografi 2013, Universiti Malaysia Sabah.

Had, A. S. (1998). Latihan perguruan untuk sekolah berkesan. Prosiding Seminar Kebangsaan JPPG, Pendidikan Guru untuk Sekolah Berkesan, Universiti Malaya, Kuala Lumpur.

Hashim, M. (2007). Kecenderungan pelajar Universiti Pendidikan Sultan Idris (UPSI) memilih minor Geografi. Tanjong Malim: Universiti Pendidikan Sultan Idris.

Hasibuan, H. (2016). Studi kompetensi guru Pendidikan Agama Islam dalam pelaksanaan evaluasi pembelajaran. Forum Paedagogik, 8(2), 14-38.

Hisham, M. N. (2011).Pengajaran dan pembelajaran: Penelitian semula konsepkonsep asas menurut perspektif gagasan islamisasi ilmu moden. Paper presented in Kongres Pengajaran Dan Pembelajaran UKM 2011, 18-20 Disember 2011, Hotel Vistana Pulau Pinang, Malaysis.

Ibrahim, M. S., Razak, A. Z. A. \& Kenayathulla, H. B. (2015). Strategi implementasi pelan pembangunan pendidikan Malaysia. Kuala Lumpur: Universiti Malaya Press.

Karademir, N. (2016). Competency level of geography students of the faculty of arts and science. Educational Research and Reviews, 11(6), 307-317. doi:10.5897/ ERR2015.2584.

Kasim, A. Y. \& Tamuri, A. H. (2010). Pengetahuan Pedagogikal Kandungan (PPK) Pengajaran Akidah: Kajian kes guru cemerlang Pendidikan Islam. Journal of Islamic and Arabic Education, 2(2), 13-30.

Kementerian Pendidikan Malaysia. (2009). Standard Guru Malaysia. Putrajaya: Kementerian Pendidikan Malaysia.

Kementerian Pendidikan Malaysia. (2013). Pelan pembangunan pendidikan Malaysia 20132015. Putrajaya: Kementerian Pendidikan Malaysia.

Koehler, M. J., Mishra, P., \& Cain, W. (2013). What is Technological Pedagogical Content Knowledge (TPACK)? Journal of Education, 193(3), 13-19. doi:10.1177/002205741319300303.

Konting, M. M. (2000). Kaedah Penyelidikan Pendidikan. Kuala Lumpur: Dewan Bahasa dan Pustaka.

McClelland, D. C. (1973). Testing for competence rather than for intelligence. American Psychologist, 28, 1-14, doi:10.1037/ h0034092.

McMillan, J. H., \& Schumacher, S. (1989). Research in education: A conceptual introduction. (Second ed.). Glenview, IL: Scott, Foresman.

Nessipbayeva, O. (2012). The competencies of the modern teacher. Paper presented at the Annual Meeting of the Bulgarian Comparative Education Society, 10th, Kyustendil, Bulgaria, Jun 12-15, 2012.

Nur Soleha, A. R. (2012). Transformasi politeknik: kesediaan pensyarah Politeknik Sultan Salahuddin Abdul Aziz Shah ke arah penubuhan Universiti Politeknik. Paper presented in Persidangan Kebangsaan Penyelidikan dan Inovasi dalam Sistem Pendidikan dan Latihan Teknikal dan Vokasional (CiETVET2012), 25-26 September 2012, Politeknik Nilai, Negeri Sembilan, Malaysia.

Ondigi, S. R. (2012). Role of Geography and Pedagogical Approaches used in the 
Training of Pre-service Teachers in Kenyan Universities: A Case of Kenyatta University, Kenya. International Journal of Academic Research in Progressive Education and Development, 1(4), 256281.

Ozdemir, U. (2012). High school students' attitudes towards geography courses (Karabuk Sample-Turkey). World Applied Sciences Journal,17(3), 340-346.

Richardson, V. (1996). The role of attitudes and beliefs in learning to teach. In J. Sikula (Ed.), Handbook of research on teacher education (2nd ed., pp. 102-119). New York: Macmillan.

Ridzwan, C. R., Malik, S., Zaliza, H., Suriani, M., Mohd Azlan, H. \& Shafeeqa S. (2017). Skills and knowledge competency of technical and vocational education and training graduate. Asian Social Science, 13(4), 69-77.

Saedah, S., \& Sani, M. I. (2012). Standard kompetensi guru Malaysia.Skudai: Universiti Teknologi Malaysia.

Sahin, A. E. (2004). Determination of teacher competencies. Bilim Ve Aklin Aydinliginda Egitim Dergisi,58,79-84.

Seman, M. \& Zuhir, A. R. (2006). Strategi penilaian pembelajaran kemahiran mendengar dan bertutur bahasa Arab. In Mohd Rosdi, I. \& Mat Taib, P. (Eds), Pengajaran dan pembelajaran Bahasa Arab di Malaysia(pp. 89). Kuala Lumpur: Penerbit Universiti Malaya.
Shulman, L. S. (1986). Those who understand: Knowledge growths in teaching. Educational Researcher,15(2), 4-14. doi: $10.1177 / 002205741319300302$.

Smith, J.A.(2004). Reflecting on the development of interpretative phenomenological analysis and its contribution to qualitative research in psychology. Qualitative Research in Psychology,1(1), 39-54. doi:10.1191/1478088704qp004oa.

Tucker, S. A. \& Cofsky, K. M. (1994). Competency-based pay on a banding platform. ACA Journal,3(1), 12-28.

Veloo, A. \& Raman, A. (2013).Kaedah analisis \& interpretasi data.Sintok: Universiti Utara Malaysia Press.

Weinert, F. E. (1999). Konzepte der kompetenz. Gutachten zum OECD-projekt "Definition and selection of competencies: Theoretical and conceptual foundations (DeSeCo)". Neuchatel, Switzerland: Bundesamt für Statistik.

Yahaya, A. H., Hashim, S., \& Azizuddin, F. B. M. (2006). Tahap kompetensi guru sekolah rendah terhadap pengajaran Sains dan Matematik dalam Bahasa Inggeris. Universiti Teknologi Malaysia. 


\section{Appendix}

An Observation Instrument according to Theme, Action Level and Quality Level Rubric

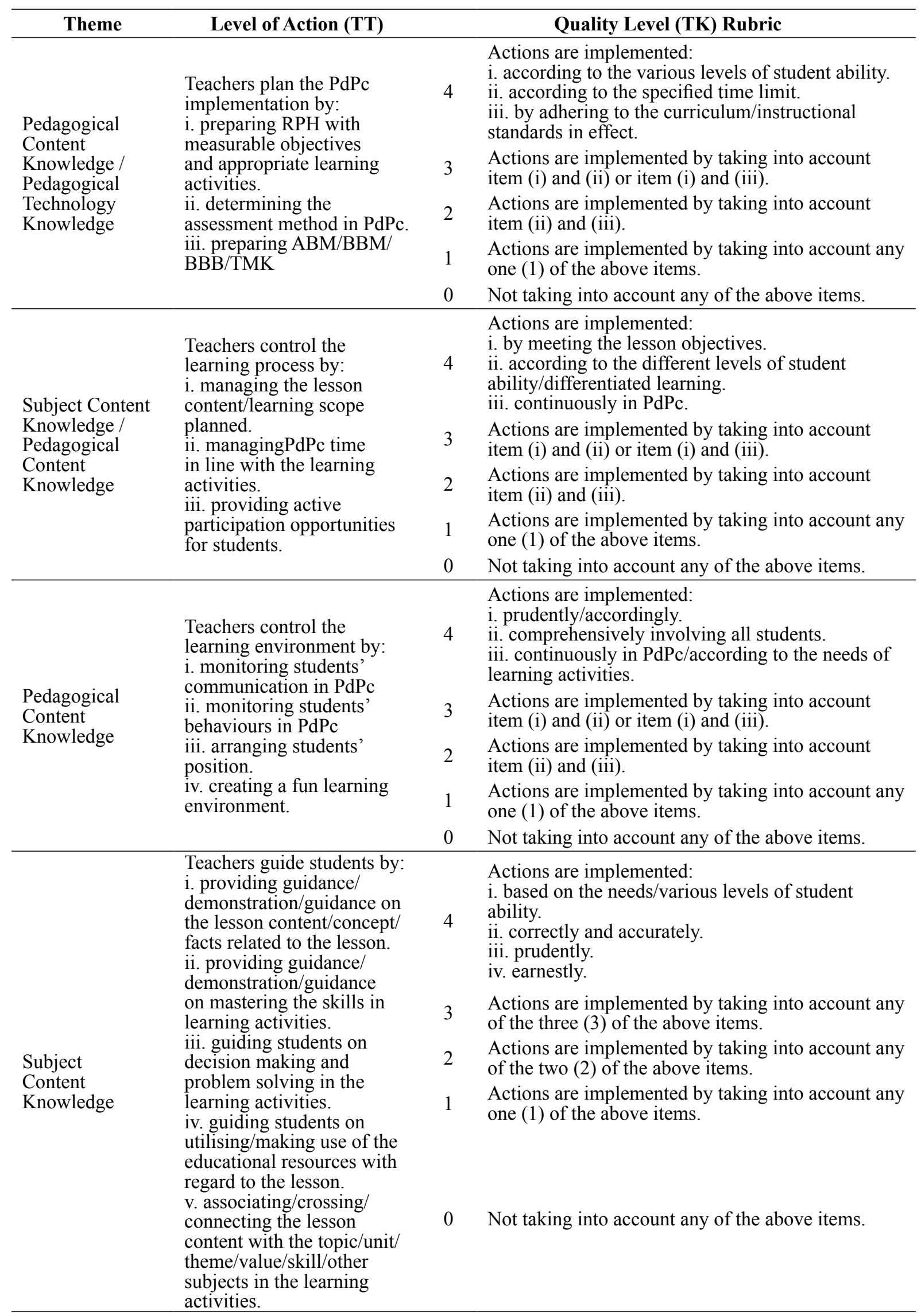




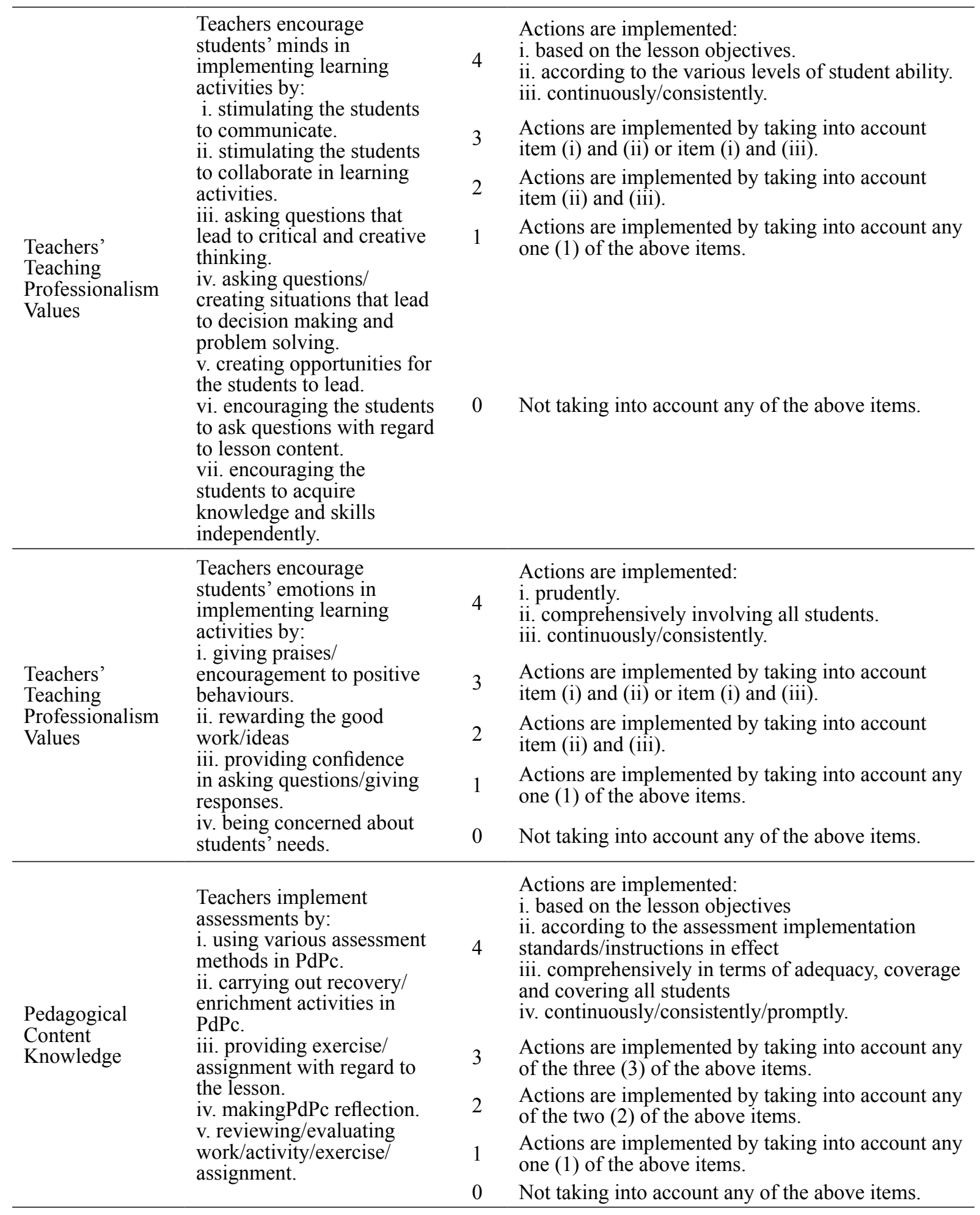


Students are involved in the learning process by:

i. responding to the lesson content.

ii. communicating in carrying out the learning activities.

iii. implementing the learning activities collaboratively.

Students' Feedback thinking with regard to the

\section{iv. responding in the way} of critical and creative lesson content. v. asking questions regarding the lesson content.

vi. associating the lesson content with the student life/local/global issues. vii. making decision/ solving problems with regard to the learning activities.
Actions are implemented:

i. with the involvement of $90 \%$ to $100 \%$ of students for action (i), (ii) and (iii) and the involvement of over $50 \%$ of students for action (iv), (v), (vi) and

4 (vii).

ii. in line with the objectives of the lesson.

iii. confidently.

iv. prudently/respectfully towards each other/ earnestly.

Actions are implemented:

i. with the involvement of $70 \%$ to $89 \%$ of the students for action (i), (ii) and (iii) and the

3 involvement of more than $25 \%$ to $49 \%$ of the students for action (iv), (v), (vi) and (vii).

ii. by fulfilling at least two (2) of item (ii), (iii) or (iv).

Actions are implemented: i. with the involvement of $40 \%$ to $69 \%$ of students for action (i), (ii) and (iii) and the involvement of

$210 \%$ to $24 \%$ of students for action (iv), (v), (vi) and (vii).

ii. by fulfilling at least one (1) of item (ii), (iii) or (iv).

Actions are implemented:

i. with the involvement of $1 \%$ to $39 \%$ of students for action (i), (ii) and (iii) and the involvement of

1 less than $10 \%$ of students for action (iv), (v), (vi) and (vii).

ii. by fulfilling at least one (1) of item (ii), (iii) or (iv).

$0 \quad$ Not fulfilling any of the above items. 